УДК 342.7

DOI https://doi.org/10.32837/pyuv.v0i1(30).506

\author{
О. М. Ганчук \\ orcid.org/0000-0002-3274-2880 \\ аспірант кафедри теорї та історї держави і права, \\ конституиійного та міжнародного права \\ Львівського державного університету внутрішніх справ
}

\title{
ІНСТИТУЦІОНАЛІЗАЦІЯ ПРАВ ЛЮДИНИ ЯК ОСНОВА ПРАВОПОРЯДКУ
}

У житті цивілізованого суспільства найвищою цінністю є людина, її права й свободи. Свідоме нехтування цими цінностями викликає подив, ще більший резонанс викликає виражене публічно небажання держави їх визнавати. Фундаментальність проблеми прав людини стає очевидною і у зв'язку з формуванням єдиної комунікативної системи, посиленням засобів ведення «гібридної» війни, збільшенням жертв політичних репресій.

Увага світової спільноти, яка спрямована на доктринальне констатування прав людини як ідеальної моральної основи, фундаменту будь-якого суспільства чи держави, надзвичайно важлива, разом із тим вона не в змозі щось змінити без чітко орієнтованих норм і механізмів такого захисту. Створена внаслідок інституціоналізації прав людини система інститутів оберігає індивіда від свавілля з боку інших суб'єктів, а цивілізовані формальні проєкції трансформуються 3 теоретичних у практичну площину.

Уявлення про те, що кожна людина має права, які надані їй від народження, а не даровані державою, - складова частина ліберальної демократії. Відповідно, ступінь інституціоналізації прав людини в нормативній площині, де визначені межі втручання держави, визнані спеціальні правозахисні інститути, свідчить про рух цієї держави в прогресивному гуманістичному напрямі.

Очевидно, що проблема інституціоналізації прав людини, ïi залежність від того чи іншого державного режиму багатогранна, різні їі аспекти вивчались і знайшли відбиття в численних працях вітчизняних і зарубіжних вчених: по-перше, це доробки, змістом яких є розкриття історичних аспектів і концептуальних складових категорії «права людини» з боку традиційних підходів та альтернативних моделей (М. Антонович, М. Байтіва, Т. Бик, В. Васечко, Г. Гребеньков, Д. Гудима, М. Єленкова, Д. Ковінько, А. Ковшик, А. Колодій, Н. Крестовська, Я. Лазур, І. Литвиненко, М. Марченко, О. Петришин, П. Рабінович, С. Рабінович, I. Честнов та інші); по-друге, це дослідження, в яких викладається проблема прав людини з боку чинного міжнародного права й ефективності функціонування внутрішньодержавних інституцій (С. Добрянський, О. Задорожний, Н. Колотова, М. Капітоненко, І. Ліщина,
В. Манжола, В. Муравйов, Н. Мушак, В. Речицький, Б. Сафаров, Т. Шумилова та інші); по-трете, це коло робіт, в яких окреслюються основні положення діяльності правозахисних інститутів та організацій (О. Лукашева, М. Савчин, В. Шаповал, Д. Ягунов та інші); по-четверте, це праці, в яких аналізується роль органів державної влади в забезпеченні прав людини в демократичних державах і регресивна роль таких інституцій у державах тоталітарного й авторитарного спрямування (В. Горбатенко, С. Джола, І. Жаровська, А. Марков, В. Сухонос та інші).

Метою дослідження є характеристика інституціоналізації прав людини як основи формування правопорядку в державі.

Узагальнення наявних у вітчизняній і зарубіжній літературі підходів до розуміння поняття права людини дає можливість виокремити наступні: етичний (права людини - це різновид, спосіб або форма вираження моралі), психологічний (права

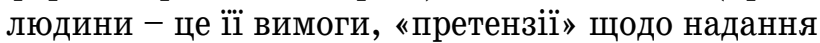
певних благ, скеровані державі чи іншим суб'єктам), біологічний (права людини - це певні її фiзичні потреби, що виникають вже із самого факту iï народження), соціальний (права людини - це певним чином соціально нормовані можливості їі поведінки, спрямованої на задоволення різних потреб), легістський (права людини - це можливості iї поведінки, визначені законами держави чи іншими формально-обов'язковими правилами).

Права людини охоплюють вимоги, повноваження, свободи й імунітети, їх можна визначати як можливості, потреби, цінності чи надбання. Більшістю прав людину наділяють різні системи правил, від статуту організації до законодавства. Чимало прав людини - це юридичні права, які людина отримує за законом. Проте слід пам'ятати, що не всі права є юридичними, або інституційними. Деякі права, зокрема природні, належать людині, навіть якщо про них нічого не зазначено в законах або в правилах інститутів.

Термін «інституціоналізація» зобов'язаний своїм походженням правовій доктрині: в другій половині II ст. саме за назвою «institutiones» був виданий підручник із римського права, де викладено усталені, апробовані часом, загальноприйняті на той час правові істини. Такий термін мав 
переважно спонукальне значення, використовувався як певна настанова до дії, орієнтир і стандарт у діяльності суспільства. Вживання такого наукового поняття дало змогу забезпечити регулювальний вплив правових настанов на суспільні відносини [5, с. 95]. Інституціоналізація - процес організації та регулювання суспільного життя, впорядкування, формалізації та стандартизації суспільних зв' язків і відносин [2, с. $181 ; 8$, с. 9].

За допомогою юридичних норм держава встановлює правопорядок, тим самим регулює i формує суспільні процеси, забезпечує фундаментальні права людини. Разом із тим інституціоналізація є суперечливим процесом, який може мати як позитивні, так і негативні (безпосередні чи віддалені) наслідки. Так, у результаті активного впливу механізмів державного регулювання інституціоналізація 3 процесу, який адекватно відбиває потреби суспільства й покликаний лише оформлювати зміст соціальних відносин у їхній об’єктивній динаміці, має тенденцію перетворення на самодостатній, пов'язаний із відтворенням самої держави процес. У такому разі інституціоналізація може чинити стримувальний вплив на адекватний розвиток суспільних відносин. Рівною мірою гуманістичні цілі, які відповідають правовому характеру держави, виступають визначальним моментом і щодо забезпечення пріоритету прав людини. Він полягає не стільки в ступені пов'язаності держави правом, скільки у виявленні й реальному здійсненні соціальних зобов'язань держави перед людиною.

Переважна більшість держав нині підтримують ідею прав людини, беруть участь у створенні міжнародних стандартів прав, включають типові переліки прав у законодавчі акти й намагаються реалізовувати їх на практиці. Водночас національно-державні модифікації прав людини диференційовані в максимальному ступені, оскільки відчувають на собі унікальну дію середовища, генерального стереотипу існування соціуму, культурно-історичної спадщини, особливості релігійного впливу в конкретній країні, тобто «права людини" в сучасному світі завжди обмежені. Однак у процесі соціалізації інститути входять у свідомість індивіда і перестають сприйматися як чужі або шкідливі обмеження.

Інституціоналізація прав людини сприяє становленню, стабільному функціонуванню та підвищенню ефективності суспільного механізму, якісному задоволенню політичних, економічних i правових інтересів індивіда.

Права людини виконують роль імперативів, які відбивають не тільки реалії, а й ідеали суспільного буття [10]. Ці імперативи виводять із наявного на рівні суспільної свідомості сприйняття справедливості й розглядають фактично як критеpiï оцінки змісту позитивного права.
Право і його вищий прояв - права людини - $€$ найважливішим інструментом впливу на стійкість суспільних процесів, воно об'єктивує свободу, автономію, параметри оптимальної взаємодії індивідів [3]. Права людини консенсуальні за своєю суттю, а тому й відіграють найважливішу роль у встановленні злагоди в суспільстві, балансуванні різних інтересів. Права людини відрізняються тенденцією до постійного розвитку й розширення. Вони охоплюють все нові сфери суспільних відносин. Забезпечення прав не може бути гарантовано в умовах застою та стагнації суспільного й правового розвитку. Тільки сталий розвиток суспільства сприяє реалізації прав і свобод. Всі найважливіші компоненти сталого суспільного розвитку кристалізуються в правах людини - політичних, особистих, економічних, соціальних, культурних.

Інституціоналізація прав людини - це процес формалізації соціальних відносин, перехід від неформальних відносин і неорганізованої діяльності до формування (передусім міжнародними [4] й державними інституціями) організаційно структурованих інституцій реалізації та захисту прав людини [6, с. 177].

Взаємовідносини між людиною та державою важлива складова частина процесів інституціоналізації. В юридичній літературі традиційно виділяють «вертикальний ефект» $\mathrm{i}$ «горизонтальний ефект» прав людини. Якщо перший («вертикальний ефект») передбачає закріплення та визнання державою широкого спектра прав - від права на життя до права на культурну самобутність, то другий (так званий «горизонтальний ефект») передбачає, що держава в особі своїх органів не тільки зобов'язана утримуватися від порушення прав людини, але й мусить захищати людину від зазіхань інших людей [7, с. 218].

В умовах інституціоналізації права людини можна визначити як поняття, що використовується для позначення конкретного переліку законодавчих положень і міжнародних стандартів. Відповідно до чинних міжнародних стандартів, з метою забезпечення правопорядку держава повинна гарантувати три групи прав: по-перше, права на незалежність від влади; по-друге, права на участь у владі - «політичні свободи й права» громадян; по-третє, економічні, соціальні й культурні права - вони є правами на соціальну допомогу 3 боку державної влади; й по-четверте, права й свободи, які обмежують державну владу або виступають засобом «захисту» від неї.

Сталий розвиток держави неможливий без забезпечення свободи й автономії особистості, яка б на вільний розсуд визначала способи й сфери своєї життєдіяльності. Дотримання прав людини запобігає всевладдю держави, яка розглядає людину як підданого, сліпого й слухняного виконавця їі волі. Встановлення партнерства між громадяни- 
ном і владою, що випливає з прав людини, запобігає політичним і соціальним катаклізмам, сприяє гармонійному розвитку суспільства, мета якого обрана й схвалена більшістю.

Права людини та їхня реалізація визначають природу держави. Водночас важливий взаємозв'язок проголошених прав і ступеня налагодженості механізмів, що визначають їхній захист. Разом iз тим, як свідчить практика, вищевикладена вимога насамперед містить у собі суперечність: з одного боку, держава часто виступає порушником прав людини, а з іншого боку, саме до державних органів людина найчастіше апелює при порушенні їі прав. У такому контексті важливо підкреслити ще одну важливу роль інституціоналізації прав людини - роль інструменту обмеження влади держави над людиною, способу вдосконалення законів, зміни законодавчої бази держави в напрямі її гуманізації [1, с. 13]. Але для того, щоб ці вимоги дійсно приводили до змін інститутів і норм держави, необхідна наявність особливих соціальних практик і структур, здатних у разі порушень прав людини діяти й домагатися потрібних змін у державній машині. Такими структурами є неурядові правозахисні організації.

Традиційно виділяють дві моделі інституціоналізації прав людини: в першій із них інститути засновуються на базі рішення органів публічної влади, а в другій - інститути формуються на практиці суспільних відносин соціально-активними громадянами, існують у вигляді фактичних правил поведінки й лише потім стають загальними правилами [9, с. 214]. Права людини як серцевина й стрижень правопорядку виступають джерелом постійного відтворення та активності, інструментом саморозвитку громадянського суспільства.

Інституціоналізація прав людини - це можливість активної громадської участі в житті суспільства й держави [2, с. 130]. Захист прав людини лише на державному рівні недостатній. Виникає потреба в створенні своєрідної системи «стримувань i противаг» державного правозахисту у формі громадських організацій, що мають універсальний характер діяльності. Дискусії про те, якими мають бути ці організації, тривають і досі. Вважаємо, що їхньою відмінною рисою має бути максимальна незалежність як від державних органів влади, так і від джерел фінансування їхньої діяльності, а основне завдання зводитись до моніторингу ситуації з правами людини й ефективної інформаційної діяльності, але не в оперуванні реальними важелями правозахисної діяльності, відмінними від правових. Їхньою відмінною рисою повинен бути суто універсальний характер діяльності як по вертикалі (закріплення та визнання державою широкого спектра прав - від права на життя до права на культурну самобутність), так i по горизонталі (держава в особі своїх органів не тільки зобов'язана утримуватися від порушення прав людини, але й мусить захищати людину від зазіхань інших).

Таким чином, аналізуючи вищевикладені змістовні характеристики інституціоналізації прав людини, їі можна визначити як процес формалізації соціальних відносин із залученням міжнародних інституцій і громадських організацій, основною метою якого є створення таких юридичних інститутів і норм, які виступатимуть інструментом обмеження державної влади, гарантом безумовної реалізації та захисту прав, свобод та інтересів людини. До атрибутивних ознак інституціоналізації прав людини слід віднести наступні:

1) інституціоналізація прав людини - це елемент соціалізації індивіда, що виводить на рівень суспільної свідомості сприйняття прав людини як певних можливостей, необхідних для задоволення її потреб;

2) інституціоналізація прав людини сприяє стабільному суспільному розвитку, виступає гарантом безумовної реалізації соціальних, економічних, політичних, культурних та інших прав, свобод, інтересів людини;

3) інституціоналізація прав людини - це процес формалізації соціальних відносин, перехід від неформальних відносин і неорганізованої діяльності до формування організаційно структурованих інституцій реалізації та захисту прав людини;

4) інституціоналізація прав людини - це інструмент обмеження влади держави, спосіб удосконалення законів у напрямі їхньої гуманізації;

5) інституціоналізація прав людини - це можливість активної громадської участі в житті суспільства й держави.

\section{Jimepamypa}

1. Антонович M.M. Еволюція поняття прав людини та проблема їх класифікації. Наукові записки НЮА. Серія «Політичні науки». 2005. Т. 45. С. 9-16.

2. Бень О.Т. Інституціоналізація: теоретична інтерпретація поняття. Вісник Львівського університету іл. І. Франка. Серія «Соиіологія». 2012. Вип. 6. C. 181-190.

3. Власенко С.Г. Інституціоналізація демократії: сутність, основні концепції, підходи. Делократичне врядування. 2015. Вип. 15. URL: http://nbuv.gov.ua/ UJRN/DeVr_2015_15 9.

4. Добрянський С.П. Юридичне гарантування дотримання прав людини інституціями Європейського Союзу: перспективи удосконалення. Право України. 2015. № 2. С. 151-162.

5. Живицький В.А. Правова інституціоналізація Державної фіскальної служби України: пріоритети реформування. Наукові праці МАУП. 2016. Вип. 48 (1). C. $95-101$.

6. Ковбасюк С.В. Сучасна інтерпретація поняття «інституціоналізація». Актуальні проблели держави $i$ права. 2009. Вип. 40. С. 177-182.

7. Леонов А.С. Государственный суверенитет и права человека: проблема совместимости и вза- 
имного влияния (теоретико-прикладной аспект). Вестник Нижегородской академии. 2013. № 21. C. 216-219.

8. Миронов Ю.Б. Інституціоналізація як соціально-економічний феномен. Науковий вісник Херсонського державного університету. Серія «Економічні науки». 2016. Вип. 17. Ч. 3. С. 9 - 11.

9. Петрушенко В.Л. Соціальний характер правових регулятивів в антропологічному вимірі. Антропологія права: філософський та юридичний виміри. Львів : Галицький друкар, 2009. С. 211 - 218.

10.Рабінович П.М. Виявлення соціальної сутності правових і державних явищ - головне завдання юридичної науки. Юридична наука. 2001. № 1 (1). C. $7-13$.

\section{Анотація}

Ганчук О. М. Інституціоналізація прав людини як основа правопорядку. - Стаття.

У статті визначено інституціоналізацію прав людини як процес формалізації соціальних відносин із залученням міжнародних інституцій і громадських організацій, основною метою якого є створення таких юридичних інститутів і норм, які виступатимуть інструментом обмеження державної влади, гарантом безумовної реалізації та захисту прав, свобод та інтересів людини. Наголошено, що у своєму арсеналі державна влада має нормативні й інституційні засоби для врегулювання різних видів соціального конфлікту. Державна влада повинна втілювати такий концепт: не людина існуе для держави, а держава існує для людини. Людське буття та вільна воля людини - це онтологічна цінність для влади в демократичній державі, а сутність людини у владі - центр побудови механізму державотворення.

Інституційний механізм забезпечення прав і свобод громадян уособлює комплекс співзалежних елементів, які надають належні юридичні й фактичні можливості для повноцінного здійснення кожним своїх прав і свобод. Акцентуючи увагу на тому, що інституційний механізм забезпечення прав людини оберігає кожного індивіда від свавілля з боку інших суб'єктів, у тому числі й самої держави, автором виокремлено такі атрибутивні ознаки інституціоналізації прав людини:

1) інституціоналізація прав людини - це елемент соціалізації індивіда, що виводить на рівень суспільної свідомості сприйняття прав людини як певних можливостей, необхідних для задоволення її потреб;

2) інституціоналізація прав людини сприяє стабільному суспільному розвитку, виступає гарантом безумовної реалізації соціальних, економічних, політичних, культурних та інших прав, свобод, інтересів людини;

3) інституціоналізація прав людини - це процес формалізації соціальних відносин, перехід від неформальних відносин і неорганізованої діяльності до формування організаційно структурованих інституцій реалізації та захисту прав людини;
4) інституціоналізація прав людини - це інструмент обмеження влади держави, спосіб удосконалення законів у напрямі їхньої гуманізації;

5) інституціоналізація прав людини - це можливість активної громадської участі в житті суспільства й держави.

Ключові слова: права людини, інституціоналізація прав людини, державна влада, правопорядок.

\section{Summary}

Ganchuk O. M. Institutionalization of human rights as the basis of law and order. - Article.

The article identifies the institutionalization of human rights as a process of formalization of social relations, involving international institutions and public organizations, whose main purpose is to create such legal institutions and norms that will serve as a tool for restriction of state power, a guarantor of the unconditional realization and protection of human rights, freedoms and interests. It is emphasized that in its arsenal state power has normative and institutional means to resolve various types of social conflict. State power should embody this concept: it is not human exists for the state, but the state exists for human. Human existence and the free will of human is an ontological value for power in a democratic state, and the essence of human in power is the center of constructing the mechanism of state formation.

The institutional mechanism for guaranteeing the rights and freedoms of citizens embodies a complex of interacting elements that provide adequate legal and factual opportunities for the full enjoyment of each of their rights and freedoms. Emphasizing that the institutional mechanism of human rights protection defends every individual from arbitrariness on the part of other subjects, including the state itself, the author outlines the following attributes of the institutionalization of human rights:

1) the institutionalization of human rights is an element of socialization of the individual that brings to the level of the public consciousness the perception of human rights as certain possibilities necessary to satisfy its needs;

2) the institutionalization of human rights contributes to stable social development, acts as a guarantor of the unconditional realization of social, economic, political, cultural and other human rights, freedoms, interests;

3) the institutionalization of human rights is the process of formalization of social relations, the transition from informal relations and unorganized activity to the formation of organizationally-structured institutions for the realization and protection of human rights;

4) the institutionalization of human rights is an instrument of restriction of the power of the state, a way of improving the laws in the direction of their humanization;

5) the institutionalization of human rights is an opportunity for active public participation in the life of society and the state.

Key words: human rights, institutionalization of human rights, state power, law and order. 